\title{
PENINGKATAN UNJUK KERJA ANTENA UNTUK TRANSMISI DATA
}

\author{
SUNARNO \\ Jurusan Teknik Fisika, Fakultas Teknik \\ Universitas Gadjah Mada
}

\begin{abstract}
Abstrak
PENINGKATAN UNJUK KERJA ANTENA UNTUK TRANSMISI DATA. Pada pengukuran radiasi jarak jauh yang sedang dikembangkan di Jurusan Teknik Fisika, Fakultas Teknik UGM, mempunyai kendala pada kualitas sistem komunikasinya. Di antara masalah yang perlu dipecahkan adalah pada sistem antena yang digunakan. Unjuk kerja antena yang optimal berpotensi meningkatkan kualitas komunikasi jarak jauh yang efektif dan meminimumkan kesalahan dalam sistem komunikasi data. Dari berbagai pengukuran parameter pada antena yang dipakai pada penelitian ini, dapat disimpulkan bahwa antena yg ditala pada frekuensi 141,6 MHz (kondisi A) jauh lebih baik dibanding ketika ditala pada frekuensi 145,0 $\mathrm{MHz}$ (kondisi B). Antena pada kondisi A dapat mencapai nilai $\rho$ minimal sebesar 0,01 sehingga return-loss terukur sebesar 53,98 dB dan field strength meter menunjukkan 1,95 volt , dibandingkan dengan antena dengan kondisi $\mathrm{B}$, di mana $\rho$ minimal hanya bisa mencapai 0,19 sehingga return- loss terukur hanya sebesar $20,44 \mathrm{~dB}$ dan pengukuran dengan field strength meter hanya sebesar 1,2 volt pada jarak yang sama dengan antena pada kondisi A. Pada penelitian ini antena yang sama telah ditala pada berbagai frekuensi, tetapi hasil yang maksimal diperoleh pada antena yang ditala pada frekuensi 141,6 MHz. Sehingga dapat diambil kesimpulan bahwa setiap antena hanya memiliki satu frekuensi kerja yang optimal pada suatu band (bukan pada band harmonisnya). Informasi ini penting dan dapat digunakan sebagai referensi bagi para praktisi di bidang sistem telemetri dan telekontrol maupun bagi para praktisi di bidang komunikasi radio.
\end{abstract}

Kata kunci: Antenna, resonance, antenna gain, SWR, telecontrolling

\begin{abstract}
ENHANCEMENT OF ANTENNA PERFORMANCE FOR DATA TRANSMISSION. In remote radiation measurements that are being developed at the Department of Engineering Physics, Faculty of Engineering Gadjah Mada University, has constraints on the quality of its communications system. The problem that needs to be resolved is on antenna system. Optimum antenna performance, potentially increase effectively telecommunication quality, and minimizing error in data communication system. In every antenna parameter measurement that used in this research, the conclusion is antenna that tuned in 141,6 MHZ frequency (A state) is more better than it tuned in 145,6 MHZ frequency (B state). Antenna in A state can reach value of $\rho$ at least 0,01 the return-loss measured at 53,98 dB and field strength
\end{abstract}


meter show 1,95 volt. It compared with B state antenna, where it has $\rho$ value at least only can reach 0.19 then return-loss measured only at $20.44 \mathrm{~dB}$ and the measuring by field strength meter only 1.2 volts in the same range with A state antenna. In this research, the same antenna is tuned in every frequency, but the maximum result has reached in antenna that tuned in 141.6 MHZ frequency. The conclusion of this research is every antenna only has one optimum working frequency in a band (but it is not harmonic band). This information is important and can be used as references for any practitioner in field of telemetry system and tele-control although for radio communication practitioner.

Keywords: Antenna, resonance, antenna gain, SWR, telecontrolling

\section{PENDAHULUAN}

Pada pengukuran radiasi jarak jauh yang sedang dikembangkan di Jurusan Teknik Fisika, Fakultas Teknik UGM, mempunyai kendala pada kualitas sistem komunikasinya. Masalah tersebut disebabkan adanya derau yang sangat signifikan yang ditimbulkan dari aktifitas perangkat elektronik dan adanya radiasi pengion di fasilitas nuklir, maupun derau dari alam di mana sistem pengukuran tersebut berada. Pada sistem pengukuran radiasi jarak jauh yang digunakan, pengiriman data menggunakan moda FSK (Frequency Shift Keying) dengan frekuensi pembawa pada band VHF (Very High Frequency). Pada sistem FSK, data yang dikirimkan berupa data binary (digital), sehingga kesalahan pada salah satu bit data dapat merusak data secara keseluruhan. Dari percobaan yang telah dilakukan, menunjukkan bahwa aktifitas radiasi dan elektronik dapat memberi gangguan berupa derau pada sistem penerima. Untuk itu diperlukan sistem pengiriman data dengan kualitas tinggi, sehingga signal yang membawa informasi digital tidak terganggu.

Antena sebagai bagian dari sistem komunikasi radio mempunyai tugas yang sangat penting, yakni untuk mengubah fenomena elektrik menjadi fenomena fotonik (gelombang Elektromagnetik) pada saat memancar dan sebaliknya, demikian juga antena bertugas untuk mengubah dari fenomena fotonik menjadi fenomena elektrik pada saat menerima. Unjuk kerja antena yang optimal berpotensi meningkatkan kualitas komunikasi jarak jauh yang efektif dan meminimumkan kesalahan dalam sistem komunikasi data. Signal yang kuat dihasilkan dari antena yang resonan pada frekuensi kerjanya. Saat ini kebanyakan para praktisi lapangan masih mengandalkan ukuran Standing Wave Ratio sebagai tolok ukur unjuk kerja antena, yakni dianggap resonan pada skala SWR serendah mungkin. Besaran Standing Wave Ratio (SWR) dapat diperoleh dengan menggunakan SWR meter. Dari penelitian ini diperoleh informasi penting bahwa pada kondisi SWR 1,0 pada SWR meter, antena belum tentu resonan, sehingga efektifitas pancaran maupun 
penerimaan belum tentu maksimal. Pada penelitian ini pengukuran parameter impedansi, reaktansi, dan faktor - $\rho$ (reflection coefficient) pada antena yang resonan diukur dan di analisis. Teknik pengukuran dan penalaan antena dengan mengacu pada ukuran impedansi, reaktansi serta faktor - $\rho$ merupakan hal baru yang sedang berkembang saat ini. Hal ini dapat dilakukan sebagai hasil dari teknologi komputasi dan perkembangan sistem pengukuran yang berbasis pada pengolah mikro yang diterapkan pada sistem antenna analyzer. Blok diagram sistem keseluruhan pada sistem telemetri dan sistem telekontrol dapat dilihat pada Gambar 1.

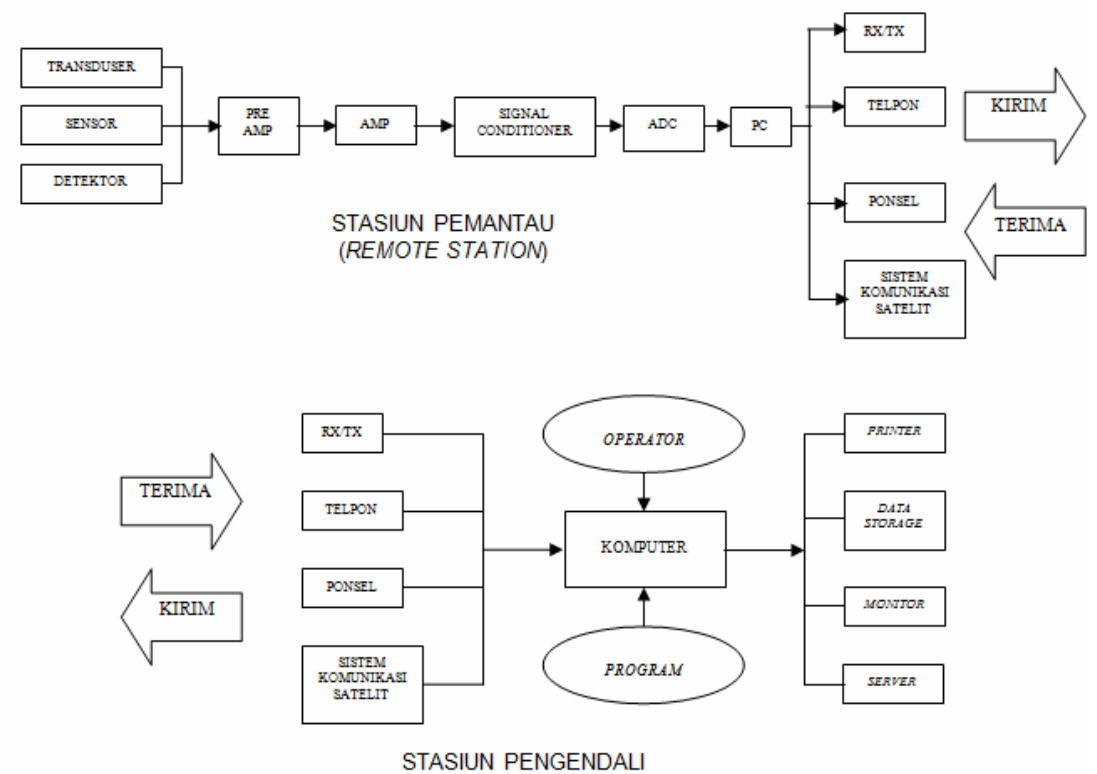

Gambar 1. Blok Diagram Sistem Pemantau dan Pengendalian Jarak Jauh ${ }^{[1]}$

\section{Resonansi pada Antena}

Resonansi pada sistem antena diartikan sebagai kondisi di mana antena pada kondisi optimal sebagai alat untuk mengubah energi elektronik menjadi energi fotonik (pada moda PANCAR) atau sebaliknya yakni mengubah energi fotonik menjadi energi elektronik (pada moda TERIMA). Dengan demikian pada kondisi resonansi ini, hampir semua energi yang dipancarkan dari perangkat pemancar, setelah melalui kabel (feeder) diubah "seluruhnya" menjadi energi foton yang dikenal sebagai gelombang elektromagnetik/gelombang radio. Sebaliknya, pada kondisi yang tidak resonan, energi yang dihasilkan dari perangkat pemancar tidak seluruhnya berubah menjadi gelombang elektromagnetik. Tergantung pada derajat resonansinya, sebagian energi akan dipantulkan balik dalam bentuk energi eletronik dan sebagian menjadi panas. Energi non fotonik tersebut selain 
merugikan kualitas komunikasi, juga mengakibatkan kerusakan pada unit pemancar maupun kerusakan pada elemen-elemen yang dilaluinya. Pada kasus antena sebagai sistem penerima, apabila antena tidak resonan maka energi foton yang diterimanya tidak semuanya bisa diubah menjadi energi elektronik, sehingga berakibat pada lemahnya sinyal yang diterima oleh unit penerima. Sinyal yang lemah dan berada pada level di bawah level derau mengakibatkan sinyal tersebut tidak dapat membawa informasi yang dibawanya. Hal ini memberi kegagalan pada penyampaian informasi atau data dari sistem pemancar ke sistem penerima.

Saat ini di tengah masyarakat telah banyak dijual berbagai jenis antena komunikasi, baik yang buatan luar maupun buatan industri lokal, bahkan banyak para amatir radio yang membuat dan mengembangkan berbagai jenis antena. Sayangnya, tidak semua antena yang dibuat berada pada kondisi resonansi. Bisa saja hal itu akibat dari rancangan desain yang tidak tepat, atau karena pemaksaan antena tersebut dioperasikan bukan pada frekuensi kerjanya. Bahkan di kalangan pengguna antena komunikasi muncul istilah "lari" untuk antena dengan derajat resonansi tinggi dan sebaliknya istilah "ngendon" untuk antena yang mempunyai derajat resonansinya sangat rendah walaupun dengan ukuran SWR 1,0 (dengan alat ukur SWR meter). Harus diakui, banyak kelemahan pada sistem rancang antena maupun pada sistem instalasinya yang terjadi di kalangan praktisi di Indonesia. Hal ini bisa dimengerti bahwa hal tersebut terjadi karena tingkat pengetahuan tentang antena maupun alat ukur yang dimiliki para praktisi tersebut masih minim. Alat ukur yang relatif murah untuk mengetahui unjuk-kerja antena yang ada di masyarakat kebanyakan adalah SWR meter. Sehingga banyak praktisi yang mengandalkan hasil pengukuran SWR meter dan sekaligus terlalu mempercayai hasil pengukuran tersebut untuk menilai unjuk kerja antena.

\section{Standing Wave Ratio ${ }^{[2]}$}

SWR atau Standing Wave Ratio terkadang juga disingkat dengan nama VSWR (Voltage Standing Wave Ratio). SWR sebenarnya dapat menunjukkan unjuk kerja antena secara baik, sayangnya SWR meter tidak mampu menunjukkan impedansi input suatu antena, sehingga bisa saja terjadi mismatch walau ukuran SWR meter menunjukkan skala 1:1 (SWR=1,0). Bila impedansi saluran transmisi tidak sesuai dengan impedansi transceiver maka akan timbul daya refleksi (reflected power) pada saluran yang berinterferensi dengan daya maju (forward power). Interferensi ini menghasilkan gelombang berdiri (standing wave) yang besarnya tergantung pada besarnya daya refleksi. Nilai SWR tidak mempunyai satuan.

VSWR didefinisikan sebagai perbandingan tegangan maksimum dan tegangan minimum gelombang berdiri pada saluran transmisi : 
VSWR $=$ Voltage Maximal $/$ Voltage Minimum

SWR juga dapat dinyatakan sebagai :

$$
\mathrm{SWR}=\frac{\mathrm{Vf}+\mathrm{Vr}}{\mathrm{Vf}-\mathrm{Vr}}
$$

Vf : tegangan maju ke antena (forward)

$\mathrm{Vr}$ : tegangan pantul dari antena (reflected)

Untuk pengukuran besarnya SWR ini, kebanyakan dipakai alat atau instrumen bernama SWR meter. Terkadang SWR meter tidak menunjukkan harga standing wave ratio yang sebenarnya, terutama bila SWR jauh dari nilai 1:1. Ini akibat tidak resonannya saluran transmisi. Gambar 2 menunjukkan gambar skematik pengukuran untuk penelitian ini.

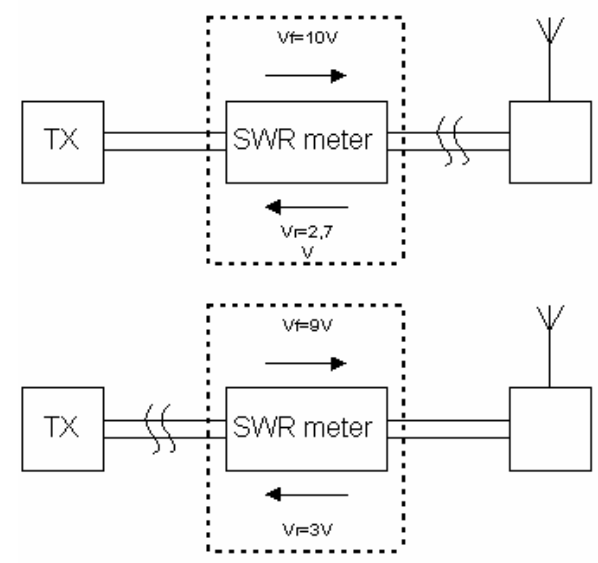

Gambar 2. Skematik Pengukuran SWR Menggunakan SWR Meter.

Posisi SWR meter diletakkan dekat dengan pemancar. Misalkan tegangan maksimum yang keluar dari TX adalah 10 volt. Karena rugi-rugi saluran, tegangan yang sampai di antena adalah 9 volt. Tegangan pantul dari antena 3 volt. Tegangan ini disalurkan ke TX yang juga mengalami redaman. Sampai di TX tinggal 2,7 volt. SWR yang terbaca :

$$
S W R=\frac{V f+V r}{V f-V r}
$$




$$
\mathrm{SWR}=\frac{10+2,7}{10-2,7}=1,73
$$

Namun bila SWR diletakkan di dekat antena (penerima), SWR yang terbaca adalah :

$$
\mathrm{SWR}=\frac{9+3}{9-3}=2,0
$$

Gambar 3 menunjukkan bentuk fisik SWR meter yang digunakan dalam penelitian ini.

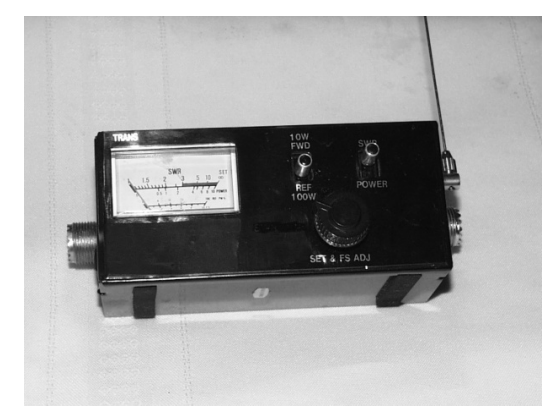

\section{Gambar 3. SWR Meter}

Pada dasarnya pengukuran SWR suatu antena berdasar pada prinsip pengukuran daya yang hilang (power lost) pada suatu jalur komunikasi yang diterminasikan pada saat resistansinya (R) sama dengan karakteristik impedansi dari jalur tersebut, dan akan meningkat apabila terjadi peningkatan SWR pada jalur komunikasi tersebut ${ }^{[3]}$.

\section{Impedansi $Z^{[4]}$}

Impedansi $\mathrm{Z}$ atau impedansi masukan merupakan perbandingan (rasio) antara tegangan dengan arus. Impedansi masukan ini bervariasi untuk nilai posisi tertentu. Sebuah Impedance $50 \mathrm{ohm}$ dapat dikomposisikan dari resistansi dan reaktansinya. Apabila impedansinya adalah $50 \mathrm{ohm}$, akan tetapi SWR tidak 1,0 (atau 1:1), reaktansi yang timbul dapat merubah nilai impedansi sesungguhnya. Jadi, dapat disimpulkan bahwa, tidak mungkin mendapatkan nilai SWR 1:1 yang sesungguhnya ketika antena dan saluran transmisinya sedang kondisi reaktif.

Pada penelitian ini juga digunakan Dummy load ${ }^{[5]}$. Dummy load digunakan untuk kalibrasi sistem pengukur SWR maupun untuk antenna analyzer. Pada dasarnya dummy load adalah resistor murni dengan resistansi sebesar $50 \mathrm{ohm}$. Pada sistem kalibrasi dummy load bekerja sebagai pengganti antena, mengingat antena yang resonan menunjukkan impedansi sebesar 50 
ohm. Impedansi $50 \mathrm{ohm}$ adalah standar impedansi output untuk radio komunikasi. Jadi selain output pemancar berimpedansi $50 \mathrm{ohm}$, kabel transmisi dan antena juga harus mempunyai impedansi sebesar $50 \mathrm{ohm}$ juga, agar transfer energi yang disalurkan bisa maksimum. Gambar 4. menunjukkan gambar fisik dummy load yang digunakan pada penelitian ini.

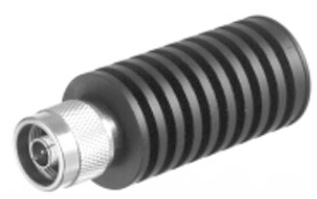

Gambar 4. Dummy Load

\section{Reaktansi Xs}

Reaktansi adalah besaran yang berupa induktansi atau kapasitasitansi suatu kabel atau sistem antena pada frekuensi tertentu. Antena akan bekerja maksimal apabila hampir semua energi yang disalurkan berubah menjadi energi elektromagnetik (bersifat foton), atau sering disebut antena yang resonan yaitu apabila reaktansinya sama dengan nol $\left(X_{s}=0\right){ }^{[6]}$. Pengukuran $X s$ saat ini hanya bisa dilakukan apabila kita menggunakan antenna analyzer (kebanyakan berbasis mikroprosesor), sedangkan SWR meter belum memungkinkan untuk mengukur besaran Xs.

\section{Faktor - $\rho$ (Ro Factor $)^{[4]}$}

Faktor ro atau reflection coefficient dapat diartikan sebagai rasio dari beda potensial yang dipantulkan (reflected voltage) dan Beda potensial awal (incident voltage). Faktor- $\rho$ adalah bilangan yang tidak mempunyai satuan. Dapat dirumuskan sebagai :

$$
\rho=E_{r} / E_{f}
$$

dengan :

$\rho=$ reflection coefficient

$\mathrm{E}_{\mathrm{l}}=$ Beda Potensial Pantulan

$\mathrm{E}_{\mathrm{f}}=$ Beda Potensial Insiden (awal)

Pada antena yang resonan, besarnya $\rho$ mendekati nol. Semakin kecil harga $\rho$ semakin tinggi unjuk kerja antena. Besaran $\rho$ dan $X_{\mathrm{s}}$ secara bersama-sama pada antenna analyzer dapat memberikan ukuran RL (Return Loss) suatu antena pada frekuensi tertentu. Nilai RL apabila dibandingkan dengan antena 
standar yang terkalibrasi dapat memberikan perkiraan besarnya Gain antena tersebut pada frekuensi tertentu.

\section{PERCOBAAN DAN TEKNIK PENGUKURAN}

Langkah penelitian:

a. membuat antena

b. meresonansikan kabel

c. mengukur antenna

d. tuning antena pada frekuensi kerja

Alat yang digunakan:

a. SWR meter

b. MFJ SWR Analyzer

c. Anritsu Antenna Analyzer

d. Field strength meter

Pada penelitian ini, setelah menala antena pada berbagai frekuensi kerja (sebagai bahasan dipakai frekuensi 141,6 MHz dan frekuensi 145,0 MHz), diukur besaran SWR, Xs, impedansi, faktor- $\rho$ dan kekuatan medannya. Pengukuran SWR, Xs, impedansi, faktor- $\rho$ menggunakan Anritsu antenna analyzer dan MFJ antenna analyzer. Sedangkan kuat medan digunakan field strength meter.

\section{HASIL PERCOBAAN DAN ANALISIS}

Pada percobaan dalam penelitian ini, digunakan sebuah antena jenis $5 / 8$ lambda dengan panjang batang yang bersifat teleskopis dan ditala (matching) pada frekuansi 141,6 MHz, selanjutnya disebut antena dengan kondisi A, dan antena yang sama ditala pada frekuensi $145,0 \mathrm{MHz}$ yang selanjutnya disebut dengan antena dengan kondisi $\mathrm{B}$.

Pengambilan data SWR, Z, Xs, faktor $-\rho$, untuk Antena pada kondisi A.

Tabel 1 merupakan tabel hasil pengukuran antena pada kondisi A, yakni antena yang di-match-kan pada frekuensi 141,6 MHz.

Tabel 1 dan Gambar 5 menunjukkan SWR yang terendah yakni 1,0 atau (1:1) menurut dua analyzer yang berbeda. Antena mulai memburuk unjuk kerjanya (lebih dari 1,5) mulai dari frekuensi 144,0 $\mathrm{MHz}$ dan kurang dari frekuensi 138,0 MHz (rentang $6 \mathrm{MHz}$ ). 
Tabel 1. Hasil Pengukuran untuk Antena kondisi A

\begin{tabular}{ccccccc}
\hline \multirow{2}{*}{$\begin{array}{c}\text { Frequency } \\
(\mathrm{MHz})\end{array}$} & $\begin{array}{c}\text { RL } \\
(\mathrm{dB})\end{array}$ & SWR & $\begin{array}{c}\text { RL } \\
(\mathrm{dB})\end{array}$ & SWR & & $\begin{array}{c}\text { Field Strength } \\
\text { Meter (Volt) }\end{array}$ \\
\hline 132.00 & 9,4 & 2,03 & 6,01 & 2,7 & 0,46 & - \\
133.00 & 10,43 & 1,86 & 6,5 & 2,4 & 0,42 & - \\
134.00 & 11,37 & 1,74 & 7,4 & 2,3 & 0,41 & - \\
135.00 & 12,29 & 1,64 & 7,7 & 2,3 & 0,4 & - \\
136.00 & 12,99 & 1,58 & 7,8 & 2,2 & 0,38 & 1,21 \\
137.00 & 13,6 & 1,53 & 8,3 & 2 & 0,33 & 1,66 \\
138.00 & 14,38 & 1,48 & 9,5 & 1,7 & 0,27 & 2,03 \\
139.00 & 15,65 & 1,4 & 11 & 1,4 & 0,19 & 2,08 \\
140.00 & 18,86 & 1,25 & 14 & 1,2 & 0,09 & 2,01 \\
141.60 & 53,98 & 1 & 20 & 1 & 0,01 & 1,95 \\
142.00 & 30,46 & 1,07 & 34 & 1,2 & 0,1 & 1,87 \\
143.00 & 19,83 & 1,23 & 19 & 1,4 & 0,18 & 1,76 \\
144.00 & 15,49 & 1,41 & 14 & 1,5 & 0,21 & 1,77 \\
145.00 & 13,27 & 1,56 & 13 & 1,7 & 0,25 & 1,78 \\
146.00 & 12,04 & 1,67 & 11 & 1,7 & 0,27 & 1,62 \\
147.00 & 11,53 & 1,72 & 11 & 1,8 & 0,29 & 1,59 \\
148.00 & 11,24 & 1,76 & 10 & 1,9 & 0,32 & 1,42 \\
149.00 & 10,78 & 1,81 & 9,6 & 2,2 & 0,39 & 1,50 \\
150.00 & 10,31 & 1,88 & 8,1 & 2,7 & 0,46 & 1,64 \\
\hline
\end{tabular}

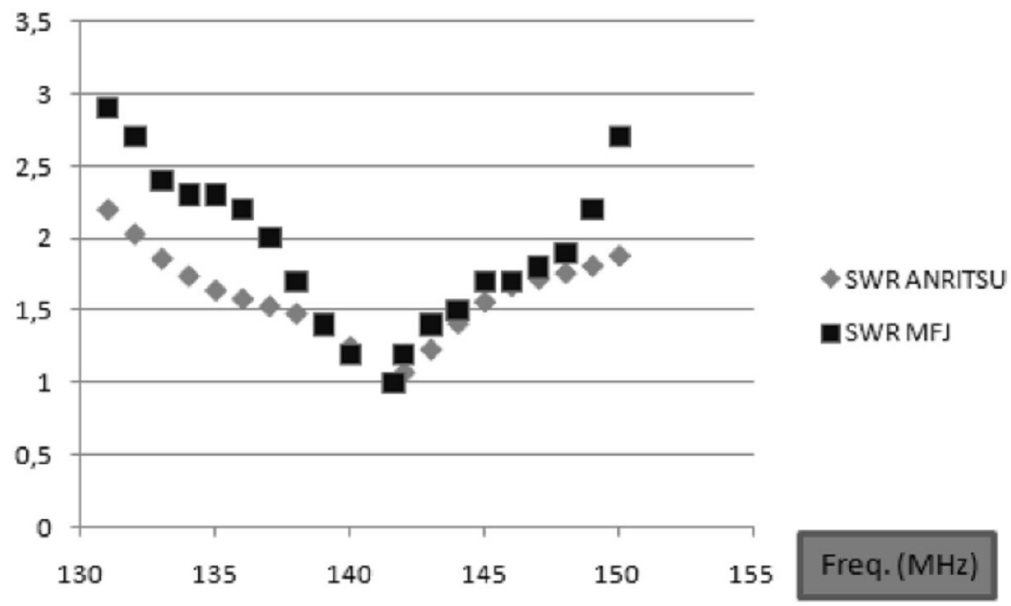

Gambar 5. Grafik Hasil Pengukuran SWR Antena Pada Berbagai Frekuensi Pada Band VHF

Besaran RL dan faktor $\rho$ untuk antena dengan kondisi A, juga dapat dilihat pada Gambar 6 dan Gambar 7. Sedangkan hasil pengukuran dengan menggunakan Field Strength Meter dapat dilihat pada Gambar 8. 


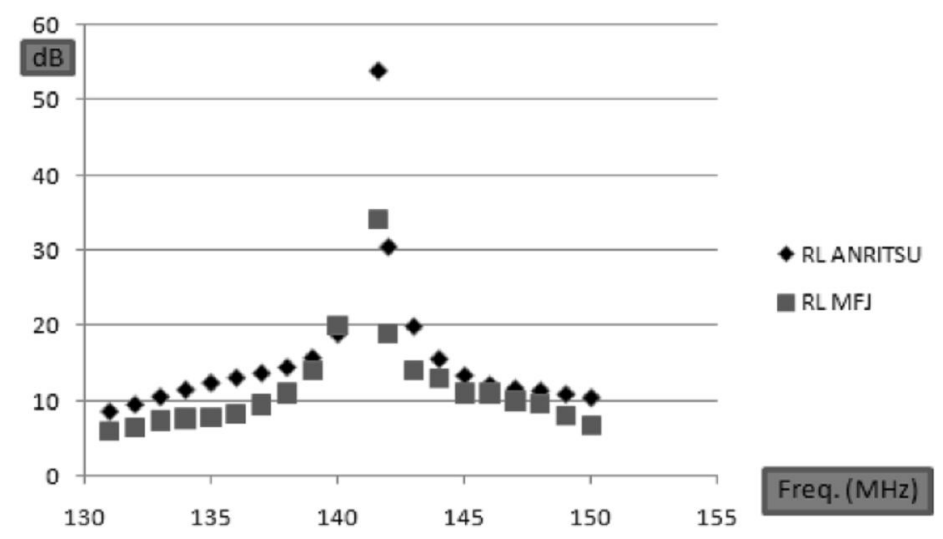

Gambar 6. Pengukuran RL Antena Dengan Kondisi A Dengan Analyzer Buatan Anritsu dan Buatan MFJ Pada Berbagai Frekuensi Uji

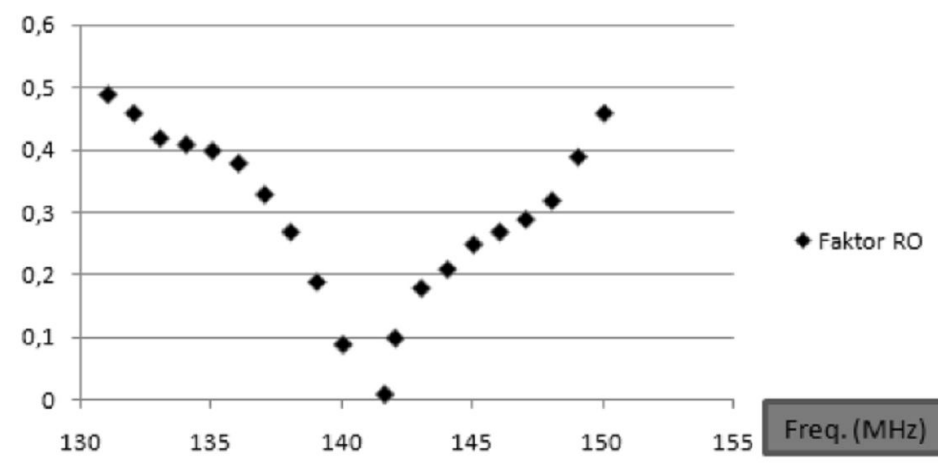

Gambar 7. Hasil Pengukuran Faktor- $\rho$ Antena (Kondisi A) Pada Berbagai Frekuensi Uji

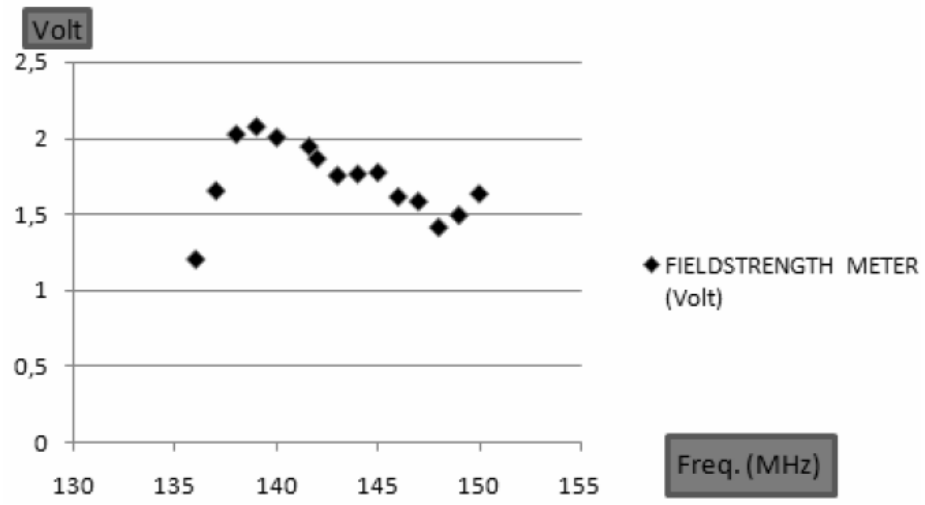

Gambar 8. Hasil Ukur oleh Fieldstrength Meter untuk Antena (Kondisi A) 
Pengambilan data SWR, $Z, X s$, faktor $\rho$, untuk Antena pada kondisi B

Tabel 2 menunjukkan data hasil pengukuran untuk antena kondisi B yang diresonansikan pada frekuensi $145.00 \mathrm{MHz}$.

Tabel 2. Hasil Pengukuran untuk Antena Kondisi B

\begin{tabular}{|c|c|c|c|c|c|c|}
\hline \multirow{2}{*}{$\begin{array}{c}\text { Frequency } \\
(\mathrm{MHz})\end{array}$} & \multicolumn{2}{|c|}{ Anritsu } & \multicolumn{3}{|c|}{ MFJ } & \multirow{2}{*}{$\begin{array}{c}\text { Field } \\
\text { Strength } \\
\text { Meter } \\
\text { (Volt) }\end{array}$} \\
\hline & $\begin{array}{c}R L_{A N R} \\
(\mathrm{~dB}) \\
\end{array}$ & SWR & $\begin{array}{r}R L_{M F J} \\
(\mathrm{~dB})\end{array}$ & SWR & & \\
\hline 135.00 & 9,66 & 1,98 & 5,5 & 3,2 & 0,52 & \\
\hline 136.00 & 9,92 & 1,93 & 5,6 & 3,2 & 0,52 & 0,97 \\
\hline 137.00 & 9,98 & 1,92 & 5,8 & 3 & 0,57 & 1,17 \\
\hline 138.00 & 9,9 & 1,93 & 6,2 & 2,9 & 0,48 & 1,42 \\
\hline 139.00 & 9,76 & 1,95 & 6,9 & 2,6 & 0,45 & 1,74 \\
\hline 140.00 & 10,14 & 1,89 & 8,2 & 2,2 & 0,38 & 1,94 \\
\hline 141.00 & 11,24 & 1,25 & 10 & 1,8 & 0,3 & 1,78 \\
\hline 142.00 & 13,1 & 1,56 & 12 & 1,5 & 0,22 & 1,63 \\
\hline 143.00 & 15,6 & 1,39 & 14 & 1,4 & 0,18 & 1,44 \\
\hline 144.00 & 18,56 & 1,26 & 15 & 1,4 & 0,17 & 1,36 \\
\hline 145.00 & 20,44 & 1,21 & 14 & 1,4 & 0,19 & 1,2 \\
\hline 146.00 & 19,17 & 1,24 & 13 & 1,5 & 0,2 & 1,16 \\
\hline 147.00 & 17,14 & 1,32 & 14 & 1,4 & 0,19 & 1,37 \\
\hline 148.00 & 15,81 & 1,38 & 15 & 1,3 & 0,16 & 1,3 \\
\hline 149.00 & 15,39 & 1,4 & 16 & 1,3 & 0,14 & 1,29 \\
\hline 150.00 & 15,44 & 1,4 & 14 & 1,4 & 0,18 & 1,33 \\
\hline 151.00 & 14,89 & 1,44 & 12 & 1,6 & 0,25 & 1,46 \\
\hline 152.00 & 13,51 & 1,53 & 9.4 & 2 & 0,33 & 1,72 \\
\hline 153.00 & 11,84 & 1,68 & 7,4 & 2,4 & 0,42 & 1,78 \\
\hline 154.00 & 10,31 & 1,87 & 6,2 & 2,9 & 0,48 & 1,75 \\
\hline
\end{tabular}

Tabel 2 menunjukkan hasil pengukuran untuk antena pada kondisi B, data menunjukkan berbagai parameter hasil pengukuran untuk berbagai frekuensi kerja pada band VHF. 


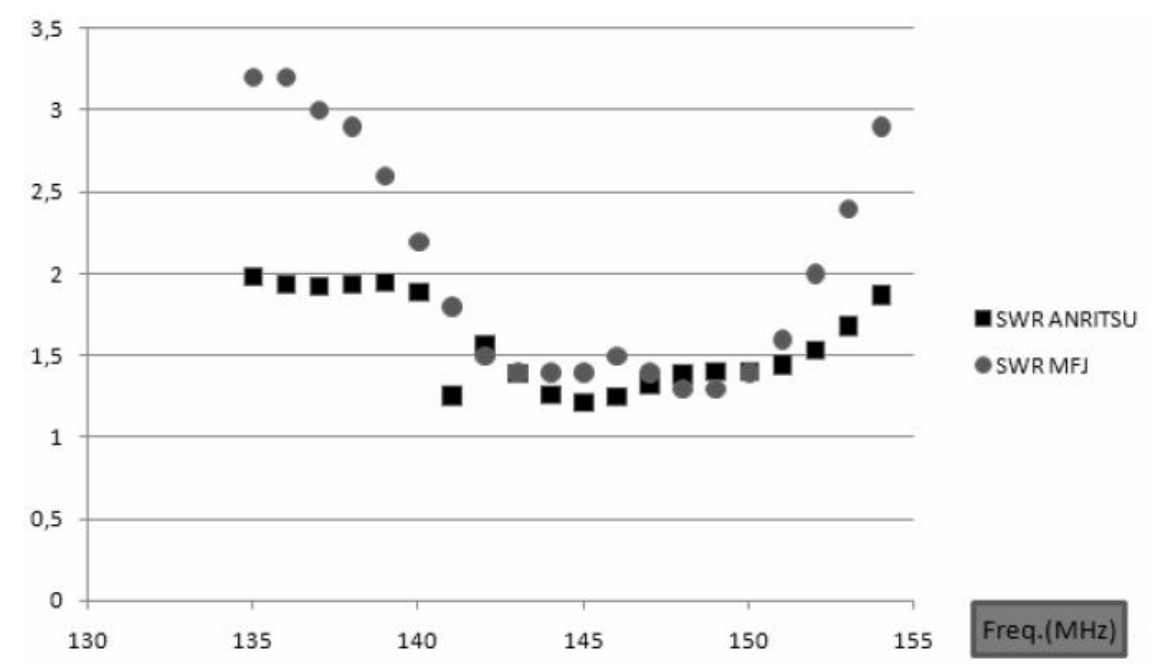

Gambar 9. Hasil Pengukuran SWR Dengan Anritsu Antenna Analyzer dan SWR Dengan MFJ Antenna Anlyzer

Tabel 2 dan Gambar 9 menunjukkan SWR yang terendah yakni 1,2 menurut dua analyzer yang berbeda. Antena mulai memburuk unjuk kerjanya (lebih dari 1,5) mulai dari frekuensi 151,0 $\mathrm{MHz}$ dan kurang dari frekuensi 143,0 $\mathrm{MHz}$ (rentang $8 \mathrm{MHz}$ ).

Besaran RL dan faktor $\rho$ untuk antena dengan kondisi $\mathrm{B}$, juga dapat dilihat pada Gambar 10 dan Gambar 11. Sedangkan hasil pengukuran dengan menggunakan Field Strength Meter dapat dilihat pada Gambar 12.

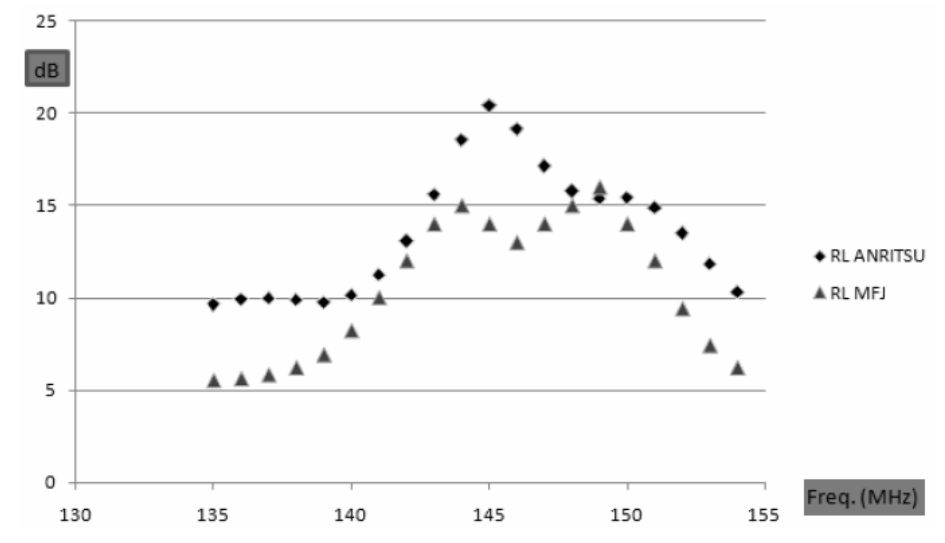

Grafik 10. Return Loss Menurut Anritsu Antenna Analyzer dan Menurut MFJ Antenna Analyzer.

Pada Gambar 10 terlihat performansi return loss yang berbeda antara Anritsu dan MFJ, dua alat ukur yang digunakan dalam penelitian ini. Return loss 
merupakan nilai perbedaan dalam $\mathrm{dB}$ antara power forward dan power pantulan antena. Pada frekuensi $145 \mathrm{MHz}$, anritsu menunjukkan nilai RL yang lebih tinggi dibanding hasil yang ditunjukkan oleh MFJ. Dari hasil pembandingan yang telah dilakukan, anlyzer buatan Anritsu mampu mereduksi pengaruh pentanahan yang tidak sempurna atau pengaruh induksi lingkungan pengukuran, sementara yang buatan MFJ tidak dilengkapi dengan fasilitas adaptasi sistem pentanahan. Harga buatan Anritsu sepuluh kali lebih mahal dibanding buatan MFJ (sekitar \$400).

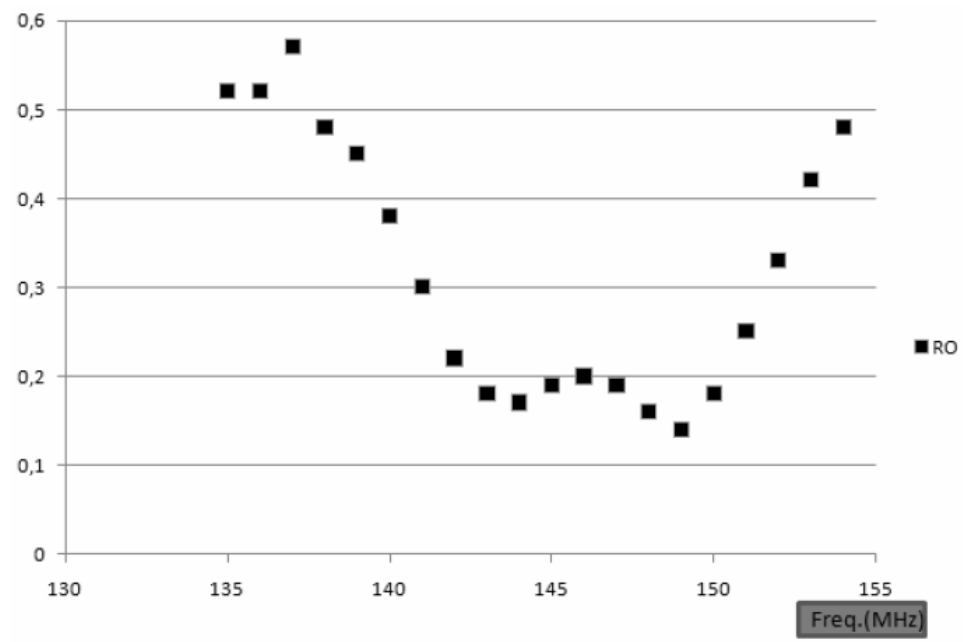

Gambar 11. Faktor $\rho$ Antena (B)

Faktor- $\rho$ atau reflection coefficient dapat diartikan sebagai rasio dari beda potensial yang dipantulkan (reflected voltage) dan Beda potensial awal (incident voltage). Faktor- $\rho$ adalah bilangan yang tidak mempunyai satuan. Dalam Gambar 11 terlihat bahwa pada frekuensi kerjanya faktor ro mengecil, antena yang sangat baik ditunjukkan dengan nilai faktor- $\rho$ nya mengecil pada frekuensi kerjanya atau mendekati 0 . Pengukuran Faktor- $\rho$ dalam penelitian ini memanfaatkan spesifikasi yang dimiliki oleh analyzer buatan MFJ yang tidak ditampilkan pada analyzer buatan Anritsu. 


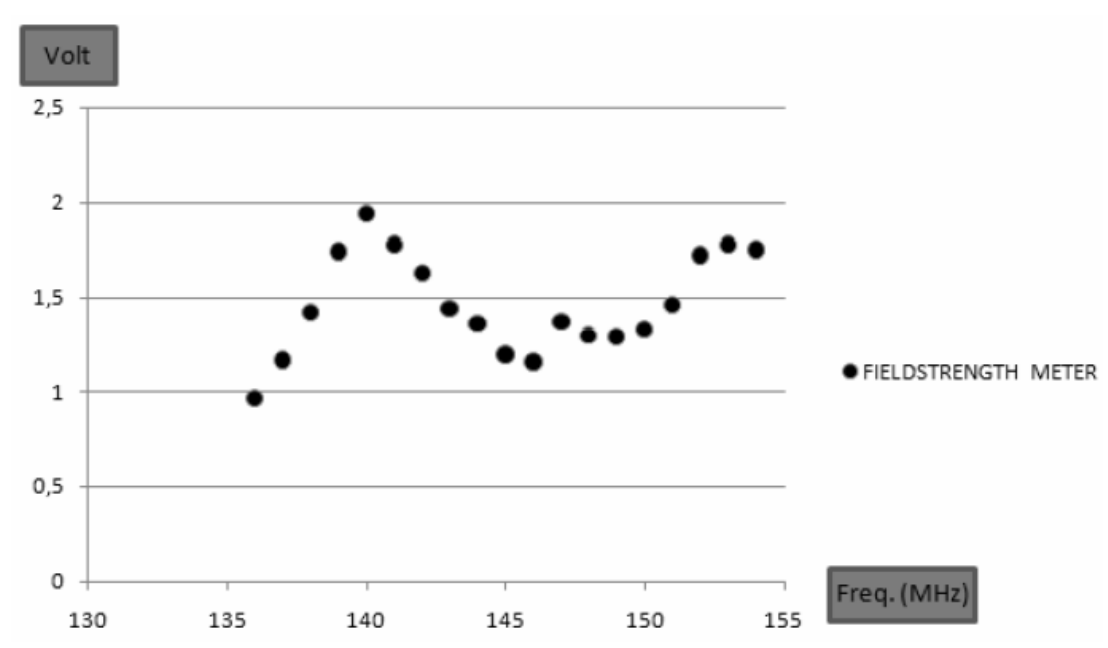

Gambar 12. Hasil Ukur oleh Fieldstrength Meter untuk Antena (B)

Dari berbagai pengukuran parameter di atas tampak bahwa antena pada kondisi A jauh lebih baik dibanding dengan antena pada kondisi B. Hal ini bisa dilihat pada tabel dan grafik hasil pengukurannya, antena pada kondisi A dapat mencapai nilai $\rho$ minimal sebesar 0,01 sehingga RL terukur sebesar 53,98 dan field strength meter menunjukkan 1,95 volt dibandingkan dengan antena dengan kondisi $\mathrm{B}$, di mana $\rho$ minimal hanya bisa mencapai 0,19 sehingga RL terukur hanya sebesar 20,44 dan pengukuran dengan field strength meter hanya sebesar 1,2 volt pada jarak dan daya yang sama dengan antena pada kondisi A, yakni jarak antara antena dan field strength meter yang ditentukan sebesar $2 \mathrm{~m}$, dengan daya pemancar sebesar 0.6 watt menurut alat ukur daya pancar (watt meter).

Pada penelitian ini antena yang sama telah ditala pada berbagai frekuensi, tetapi hasil yang maksimal diperoleh pada antena dengan kondisi A. Sehingga dapat disimpulkan bahwa setiap antena hanya memiliki satu frekuensi kerja yang optimal pada suatu band (bukan pada band harmonisnya).

\section{KESIMPULAN}

1. Antena sebagai bagian dari sistem komunikasi mempunyai tugas sangat penting yakni untuk mengubah fenomena elektrik menjadi fenomena fotonik (gelombang Elektromagnetik) pada saat memancar dan sebaliknya, mengubah dari fenomena fotonik menjadi fenomena elektrik pada saat menerima. Unjuk kerja antena yang optimal berpotensi 
meningkatkan kualitas komunikasi jarak jauh yang efektif dan minimnya kesalahan dalam sistem komunikasi data.

2. Dari berbagai pengukuran parameter dapat disimpulkan bahwa antena pada kondisi A jauh lebih baik dibanding dengan antena pada kondisi B. antena pada kondisi A dapat mencapai nilai $\rho$ minimal sebesar 0,01 sehingga RL terukur sebesar 53,98 dan field strength meter menunjukkan 1,95 volt, dibandingkan dengan antena dengan kondisi B, di mana $\rho$ minimal hanya bisa mencapai 0,19 sehingga RL terukur hanya sebesar 20,44 dan pengukuran dengan field strength meter hanya sebesar 1,2 volt pada jarak dan daya yang sama dengan antena pada kondisi A (jarak $2 \mathrm{~m}$ dengan daya sebesar 0,6 watt).

3. Pada penelitian ini antena yang sama telah ditala pada berbagai frekuensi, tetapi hasil yang maksimal diperoleh pada antena dengan kondisi A. Sehingga dapat disimpulkan bahwa setiap antena hanya memiliki satu frekuensi kerja yang optimal pada suatu band (bukan pada band harmonisnya).

4. Informasi hasil penelitian ini sangat penting sebagai referensi bagi para praktisi di bidang telemetri dan telekontrol, serta bagi para praktisi di bidang komunikasi radio.

\section{UCAPAN TERIMA KASIH}

Terimakasih kepada saudara Memory Motivanisman, Rony Wijaya, Dwi Joko Suroso, Winarno, Andi, dan Johan atas bantuannya dalam penelitian ini. Juga terimakasih kepada PT. Datto Asia Technology atas bantuan peminjaman peralatan untuk analisis.

\section{PUSTAKA}

1. SUNARNO, Instrumentasi, Diktat Mata Kuliah Instrumentasi, Jurusan Teknik Fisika, UGM ; 2009.

2. http://www.elektroindonesia.com/elektro/el02e.html

3. ARRL Antenna Book, The American Radio Relay League Inc, 21st edition; 2007.

4. KRAUS D. JOHN and RONALD J. MARHEFKA, Antennas For All Applications, 3rd edition, Mc Graw Hill; 2002.

5. www.migas-Indonesia.com/files/. /\%5BElectrical\%5DDummyLoad.doc

6. MFJ HF/VHF/UHF Analyzer, MFJ Enterprises, inc; 2002. 
